\title{
FENOMENA LIVING AL-QUR'AN DALAM PERSPEKTIF NEAL ROBINSON, FARID ESACK DAN ABDULLAH SAEED
}

\author{
Tinggal Purwanto
}

\begin{abstract}
This paper explored the idea of Neal Robinson, Farid Esack and Abdullah Saeed in their books, Discovering The Qur'an: A Contemporary Approach To A Veiled Text, The Qur'an: A User's Guide, and The Qur'an: An Introduction in order to understand the living Qur'an in moslem society. After reading these books, the writer found that the Qur'an gave a strong presence in the lives of many Muslims. Various norms and practices concerning interaction with the Qur'an have developed over time. Recitation of the Qur'an was not only as Islamic artistic expression but also as a good reward. Memorizing al-Qur'an is a demand and a need for many Muslims. In modern era, on one hand, the Qur'an is always listened by electronic media, on the other hand, the Qur'an was used as a protection from evil by wearing it as amulet. Ayahs of Qur'an and certain surahs were believed that they have superiority and were recitated at specific times. Arabic calligraphy was considered one of the most important forms of Islamic artistic expressions. All in all,the Qur'an was not only a guidance but also an ideology.
\end{abstract}

Keywords: Living Qur'an, Muslim, recitation, memorizing, and Arabic calligraphy.

\section{Pendahuluan:}

\section{Al-Qur'an dan Interaksi Umat Islam}

Al-Qur'an diyakini mencakup segala hal dan bersifat universal. Kandungan al-Qur'an yang begitu istimewa itulah yang menyebabkannya dianggap sebagai mukjizat paling agung sepanjang zaman, yang diturunkan kepada umat manusia lewat Rasulullah saw. Ia merupakan inspirasi dan petunjuk yang memiliki kandungan makna yang sangat kaya, luas, dan mendalam sehingga

\footnotetext{
Dosen STAIN Syaikh Abdurrahman Siddik Bangka Belitung. email : tinggal_purwanto@yahoo.com
} 
setiap lafaznya bisa memunculkan banyak makna dan arti, sesuai dengan kemampuan dan cara pembacaan seseorang. ${ }^{2}$

Interaksi umat Islam dengan kitab sucinya, al-Qur'an sepanjang masa telah memberikan efek yang sangat luar biasa dalam kehidupan social kemasyarakatan dan memposisikannya sebagai satu-satunya kitab suci yang mendapatkan tempat yang paling terhormat di hati pembacanya dan pengamalnya. Sebagaimana diungkapkan Abdullah Saeed sebagai berikut:

"Given the strong presence of the Qur'an in the lives of many Muslims, various norms and practices concerning interaction with the Qur'an have developed over time. Some of these practices are universal, known to most Muslims, regardless of the time or place in which they live, while others may be specific to a certain culture or time.",3

Dari penjelasan di atas, ditegaskan bahwa al-Qur'an diyakini memberikan pengaruh yang luar biasa dalam kehidupan masyarakat. Hal ini dapat dilihat dari banyaknya norma, aturan, ataupun praktik yang berhasil dibangun dalam sebuah interaksi antara al-Qur'an dengan umat Islam yang senantiasa berkembang sepanjang zaman. Secara jelas, beberapa praktik keagamaan yang didasarkan atas pemahamannya terhadap al-Qur'an ini, secara umum, diketahui oleh mayoritas muslim. Meski ada beberapa praktik yang secara spesifik hanya terdapat di daerah atau budaya tertentu.

Interaksi antara komunitas muslim dengan kitab sucinya, al-Qur'an, dalam lintasan sejarah Islam, senantiasa mengalami perkembangan yang dinamis. Interaksi umat Islam dengan al-Qur'an menjadi pengalaman beragama yang sangat bernilai. Pengalaman beragama ini dapat diungkapkan dengan cara mengekspesikannya melalui lisan, tulisan, maupun perbuatan, baik berupa pemikiran, pengalaman emosional maupun spiritual. Selanjutnya, interaksi yang intens ini dilakukan untuk mendapatkan yang bermakna sesuai dengan latar belakang, tujuan, metode maupun pendekatan yang dikembangkan.

\footnotetext{
${ }^{2}$ Hasan Baharun, "Mohammed Arkoun: Pendekatan Antropologi dalam Membumikan alQur'an dalam Metodologi Studi Islam: Percikan Pemikiran Tokoh dalam Membumikan Agama (Yogyakarta: Ar-Ruzz Media, 2011), hlm. 240. 2008), hlm. 84 .

3 Abdullah Saeed, The Qur'an: An Introduction (London and New York: Routledge,
} 
Eksisitensi al-Qur'an yang shalih li kulli zaman wa makan selalu menarik untuk diteliti, dikaji dan ditela'ah. Sejarah mencatat bahwa interaksi umat dengan al-Qur'an telah menghasilkan sekian banyak penelitian yang sudah tak terhitung jumlahnya. ${ }^{4}$ Namun studi al-Qur'an yang berkembang hingga sekarang masih berorientasi pada studi teks, dan belum banyak menyentuh aspek-aspek lain yang terkait langsung dengan sikap dan penerimaan umat pembaca terhadapnya. Maka wajar jika studi al-Qur'an oleh sebagian orang dirasa "menjenuhkan”, belum lagi aspek materi yang minim sekali berorientasi langsung kepada kebutuhan umat dan belum banyak diarahkan pada persoalan-persoalan kontemporer, misalnya kasus fenomena umat Islam yang memungsikan al-Qur'an di luar fungsinya sebagai hudan wa rahmatan li al-'alamin.

Melihat fenomena muslim dalam berinteraksi dengan al-Qur'an ini, para ilmuan telah melakukan kajian mendalam, misalnya Neal Robinson, Farid Esack dan Abdullah Saeed. Mengawali kajiannya, Abdullah Saeed mengungkapkan:

"throughout the history of Islam, the qur'an has always been much more than a legal or religious text used mainly by scholars and preachers. From its revelation in the seventh century, the Qur'an has been memorized, recited and to a lesser extent copied by people at all levels of society, from scholars to young children."

Dari kutipan di atas, jelas bahwa sepanjang sejarah Islam, al-Qur'an ternyata tidak dipahami hanya sebatas teks hukum atau keagamaan semata, tetapi lebih dari itu, dibacakan diperdengarkan, disakralkan, dan dipraktikkan dalam hampir semua aktivitas keseharian sampai acara ceremonial di berbagai lapisan masyarakat; lokal sampai internasional.

\footnotetext{
${ }^{4}$ Secara garis besar, interaksi antara komunitas muslim sebagai subjek pada satu sisi dengan al-Qur'an sebagai objek kajian pada sisi lain telah menghasilkan tiga kategori. Pertama, penelitian al-Qur'an yang menempatkan al-Qur'an sebagai sebagai objek kajian. Kedua, penelitian yang menjadikan hasil pembacaan atau pemahaman terhadap teks al-Qur'an sebagai objek kajian, baik berwujud teori-teori penafsiran maupun yang berupa pemikiran eksegetik-kitab tafsir. Ketiga, penelitian yang memberikan perhatian pada respons masyarakat atau sikap sosial terhadap teks al-Qur'an dan hasil penafsiran seseorang. Sahiron Syamsuddin, "Penelitian Literatur Tafsir/ Ilmu Tafsir: Sejarah, Metode dan Analisis Penelitian (Makalah seminar ), Yogyakarta, 1999. Disampaikan pada Sarasehan Metodologi Penelitian Tafsir-Hadis IAIN Sunan Kalijaga Yogyakarta pada tanggal 15-16 Maret 1999, hlm,1-2.

${ }^{5}$ Abdullah Saeed,The al-Qur'an: ......, h. 84.
} 
Berdasarkan latar belakang di atas, tulisan ini mencoba untuk mengeksplorasi bagaimana fenomena muslim dalam berinteraksi dengan alQur'an tersebut dengan mengacu kepada kajian-kajian yang dilakukan oleh Neal Robinson dalam bukunya Discovering The Qur'an: A Contemporary Approach To A Veiled Text sub bahasan "The Qur'an as Experienced by Muslims", Farid dalam bukunya Esack dalam bukunya The Qur'an: A User's Guide sub bahasan “The Qur'an in The Lives of Muslims" dan Abdullah Saeed dalam bukunya The al-Qur'an: an Introduction sub bahasan “Al-Qur'an in Daily Life.” Dari ketiga kajian tersebut, diharapkan deskripsi mendalam tentang fenomena muslim berinteraksi dengan al-Qur'an dapat dijelaskan dalam artikel ini.

\section{Pembahasan:}

Menelisik Fenomena Living Qur'an dalam Neal Robinson, Farid Esack dan Abdullah Saeed

\section{Pembacaan al-Qur'an: Seni Keindahan dan Manfaat}

Dalam penelitiannya di Pakistan, Neal Robinson berhasil merekam ada tiga fenomena muslim dalam memperlakukan al-Qur'an dalam bukunya Discovering The Qur'an: A Contemporary Approach to A Veiled Text, (1) bagaiman cara muslim mendengarkan al-Qur'an (listening to the Qur'an); (2) bagaimana cara muslim menghapal al-Qur'an (having the Qur'an by heart); dan (3) bagaimana al-Qur'an hadir dalam kehidupan sehari-hari umat Islam (The Qur'an in everyday life).

Hal pertama yang menarik perhatian Neal Robinson adalah masalah susunan redaksi wahyu yang pertama kali muncul, yakni QS. al-'Alaq: 1-5. Bagi Robinson, susunan sastra dan bahasa al-Qur'an sangat luar biasa. Pada aspek sastra misalnya, Robinson tertarik mengkaji rima (rhyme) dan irama (ryhthm) ayat yang pertama turun, QS. al-Alaq: 1-5. Menurutnya, ada dua hal yang menarik, sebagaimana berikut:

"First, it is immediately obvious that the original is characterized by rhyme. In fact the whole of the Qur'an is in rhymed or assonance prose, and rhyme and assonance are the basis for the subdivision of the surahs 
into ayahs. Second, although these five ayahs are unequal length, there is a marked rhythm. Short of listening to a recitation, the easiest way to appreciate this is by counting the number of isochronic units. ",

Dari kutipan di atas jelas bahwa QS. al-'Alaq:1-5 tersebut, memenuhi syarat untuk dikatakan sebuah puisi karena memiliki karakteristik rima yang jelas pada setiap akhir ayat. Bahkan menurut Robinson, tidak hanya ayat tersebut, bahkan seluruh redaksi al-Qur'an berirama atau prosa yang memiliki asonansi. Menurutnya, rima dan asonansi, keduanya menjadi dasar dalam pembagian surat ke dalam ayat-ayat al-Qur'an. Kedua, meskipun lima ayat tersebut tidak sama panjang, tetapi ada penanda ritmenya.

Selain rima dan irama al-Qur'an, menurut Robinson ada yang menarik dari aspek bahasa al-Qur'an, yakni huruf konsonan. Huruf konsonan bahasa al-Qur'an (bahasa Arab) yang dihasilkan terdengar sangat parau (a very strong guttural produced). Ia mengambil contoh misalnya pada QS. al-'Alaq, bunyi kata khalaq dan 'Alaq. Selain itu kasus kesamaan bunyi kata qalam dan ya'lam yang memiliki hubungan yang yang kuat antar keduanya (a simmilarty which establishes a strong association between them). Menurut kesimpulannya, pergeseran dari sebuah dominan suara yang berasal dari bibir adalah sangat tepat bagi al-Qur'an dalam merangkum wahyu verbal yang timbul. ${ }^{7}$

Ketertarikan Robinson lainnya adalah ketika al-Qur'an secara rutin dilantunkan selama malam bulan Ramadhan oleh umat Islam. Seperti terekam dalam statement berikut:

"During Ramadhan, muslim flock to the mosque for the night prayers which are followed by extensive Qur'anic recitations. In the course of the month, they hear not just the first revelation but all 114 surahs in their canonical order, a thirtieth or more of the Qur'an being recited each night. It is beyond the scope of the present work to give a systematic account of the auditory qualities of the whole corpus. ",

Jelas bahwa kutipan di atas menunjukkan bahwa Neal Robinson melihat fenomena muslim saat bulan Ramadhan. Bagi Robinson, pembacaan al-Quran

\footnotetext{
${ }^{6}$ Neal Robinson, Discovering The Qur'an: A Contemporary Approach To A Veiled Text (Washington: Georgetown University Press, $2^{\text {nd }}$ ed. 2003), hlm.10.

${ }_{7}$ Neal Robinson, Discovering ....., hlm. 11.

${ }^{8}$ Neal Robinson, Discovering ........hlm. 11.
} 
selama Ramadhan tidak hanya wahyu pertama tetapi seluruh surat yang jumlahnya mencapai 114 surat atau 30 juz. Menurut Robinson, paling tidak umat Islam membaca 1/30 juz atau al-Qur'an setiap malamnya. Hal ini sangat menarik karena secara sistematis akan berdampak pada peningkatan kualitas mendengarkan al-Qur'an dari seluruh corpus-nya. Bagi Robinson, Efek yang diciptakan dari fenomena pembacaan al-Qur'an selama bulan Ramadhan ini adalah rasa gembira yang luar biasa di kalangan muslim setelah mereka dapat menamatkan al-Qur'an, khususnya ketika pengkhataman al-Qur'an tersebut dilaksanakan pada malam ke-27 bulan Ramadhan, lailatul qadar.

Berdasarkan hasil penelitiannya terhadap fenomena pembacaan al-Qur'an umat Islam, Robinson menyimpulkan bahwa ada tiga bentuk pembacaan alQur'an, sebagaimana dikatakan:

"There are three standard modes of recitations: hard, the rapid mode which corresponds to normal talking speed; tartil, which is slow; and tadwir, which is at a medium pace. Finally, although it is forbidden to set the Qur'an to a preconceived melody-for this whould involve making the word of God subordinate to the dictates of music-a recitation is nonetheless a musical performance, the recite improvising in such a way as to highlight the innate musical qualities of the revelation."

Dari pernyataan di atas jelas bahwa menurut Robinson ada tiga bentuk pembacaan al-Qur'an (tilawah); (1) hadr, yakni model pembacaan secara cepat sebagaimana kecepatan orang berbicara normal (normal talking speed); (2) tartil, yakni model pembacaan al-Qur'an secara lambat (slow); dan (3); tadwir, yakni model pembacaan al-Qur'an dengan kecepatan sedang (medium pace). Lebih lanjut Robinson menjelaskan bahwa meskipun terdapat pelarangan terhadap di luar tiga model tersebut, ada sebagian para Qori yang berimprovisasi dalam membaca al-Qur'an. Menurut Robinson, model improvisasi pembacaan al-Qur'an untuk meningkatkan kualitas musical al-Qur'an (the innate musical qualities of the revelation).

Kajian Robinson terhadap aspek keindahan bahasa dan satra al-Qur'an ini hampir senada dengan penelitian selanjutnya. Farid Esack dalam bukunya The

\footnotetext{
${ }^{9}$ Neal Robinson, Discovering ......, hlm. 14.
} 
Qur'an: A User's Guide memandang fenomena ini tidak hanya sebatas aspek keindahan dalam seni baca al-Qur'an yang didengar tetapi ada harapan adanya manfaat (pahala, jaminan dll.) dari aktivitas membaca al-Qur'an. Farid Esack dalam pembahasannya "The Qur'an as the recited word of God," mengungkapkan:

"For many a believer there cannot conceivably be a greater activity than that which God Himself engages in. .....Numerous other saying attributed to the Prophet speaks of the mere recitation of the Qur'an, or parts thereof, as an act of virtue by itself independent of approaching it as a book of moral or legal guidance." 10

Menurut Esack, bagi orang Islam, aktivitas membaca al-Qur'an diyakini sebagai aktivitas yang 'paling besar pahalanya' dari Allah SWT. dan dianggap sebagai bagian dari kebajikan sekaligus sebagai pedoman moral atau hukum bagi umat Islam.

Abdullah Saeed dalam bukunya The Qur'an: An Introduction, pada pembahasannya tentang "The Qur'an in Daily life" hampir sama dengan Neal Robinson dan Farid Esack dalam memotret fenomena umat Islam dalam pembacaan al-Qur'an. Lebih dari itu ia menambahkan bahwa menghapal alQur'an juga menjadi hal yang 'menakutkan' karena dijadikan syarat masuk sekolah atau perguruan tinggi Islam. Sebagaimana diungkapkan:

"In the modern age, the task of memorizing such large amounts of text may seem daunting. However, in most parts of the Muslim world today there are still many who have committed the entire Qur'an to memory. Historically, memorization of the Qur'an was a standard part of an Islamic education, and it remains part of the curriculum in many Islamic schools and seminaries today. In some countries, memorization of part of the Qur'an is still a prerequisite for gaining entry into Islamic studies in higher education.",11

Di era modern, ketika membaca al-Qur'an hukumnya hampir bisa dikatakan wajib, ternyata dampaknya memunculkan fenomena di lingkup pendidikan. Sebagian sekolah maupun perguruan tinggi muslim, utamanya,

19.

${ }^{10}$ Farid Esack, The Qur'an: A User's Guide ( England: One World Oxpord, 2005), hlm.

${ }^{11}$ Abdullah Saeed, The Qur'an:......hlm. 85 
menjadikan pembacaan al-Qur'an sebagai prasyarat masuk sekolah atau perguruan tinggi tertentu, atau lebih dari itu, fenomena itu merambah ke lingkup materi, yakni dijadikannya baca tulis al-Qur'an sebagai bagian dari kurikulum di banyak sekolah atau perguruan tinggi.

Abdullah Saeed juga merekam bagaimana fenomena aktivitas pembacaan al-Qur'an hingga menjadi sebuah kompetisi, sebagaimana diungkapkan:

"However, in modern times, reciters with particularly beautiful voices can often become semi-professional, producing recordings of the Qur'an which are sold around the world or downloaded from the Internet. For both children and adults, there are local and national competitions in Qur'an recitation, as well as major international events held regularly throughout the Muslim world." 12

Dengan demikian, jelas bahwa pembacaan al-Qur'an menginspirasi para ahli untuk menciptakan seni baca al-Qur'an. Fenomena ini kemudian memunculkan seni pembacaan al-Qur'an dengan ke tingkat yang lebih tinggi dan lebih serius, misalnya dalam rangka kompetisi seni baca al-Qur'an dari lokal hingga internasional. Lebih jauh lagi, fenomena seni baca al-Qur'an ini disebarkan lewat media elektronik dengan cara memproduksi rekaman al-Qur'an yang bisa dijual di seluruh dunia atau di-download dari Internet. Fenomena ini hampir terjadi di semua negara muslim.

\section{Penghapalan al-Qur'an: Problem Tuntutan dan Kebutuhan}

Robinson memandang bahwa hapal al-Qur'an merupakan tuntutan bagi seorang muslim. Oleh karenanya menghapal al-Qur'an menjadi kebutuhan penting. al-Qur'an adalah bagian integral dari solat, tanpa membaca minimal tiga ayat al-Quran — selain surat al-Fatihah-dalam solat, maka solat tersebut tidak sah. Pernyataan ini sebagaimana terungkap: "For salat to be valid, the Qur'an must be recited from memory in Arabic. It is possible to fulfil one's obligatory by knowing only the fatihah and a few other passage. A selection of short surahs from the end of the Qur'an are usually learnt for this purpose." ${ }^{\prime 13}$ Dari pernyatan

\footnotetext{
${ }^{12}$ Abdullah Saeed, The Qur'an ....., hlm. 86.

${ }^{13}$ Robinson, 15.
} 
tersebut, menurut Robinson, keabsahan solat seorang muslim adalah jika ia membaca al-Qur'an dalam salatnya, yakni surat al-Fatihah ditambah surat-surat lainnya. Dengan adanya perintah solat ini, jelas bahwa seorang muslim harus menghapalkan al-Qur'an, meski tidak seluruhnya. Inilah, menurutnya, tujuan mengapa umat Islam harus menghapalkan sebagaian al-Qur'an, utamanya untuk keperluan kevalidan ibadah solat mereka.

Adanya keharusan membaca ayat al-Qur'an dalam solat, memunculkan fenomena muslim dalam menghapalkan al-Qur'an sejak usia dini. Robinson merekam fenomena aktivitas anak-anak muslim dalam menghapal al-Qur'an sebagai berikut:

"However, many muslim endeavour to memorize much more than this. It is a widespread practice for children, some as young as seven year of age, to attend a Qur'an class after school each day. ...... Only when he has read it from beginning to end and mastered the pronunciation does he attempt to commit passage to memory. At the end of three years some will have learned only a few short surahs, but others will know the whole al-Qur'an by heart and will have earned the coveted title of hafiz." 14

Setidaknya, deskripsi Robinson dapat dijelaskan bagaimana tahapantahapan yang harus dilalui umat Islam dalam mempelajari cara baca al-Qur'an hingga menghapalkannya. Menurutnya, tahapan yang harus dilalui: pertama, belajar cara pengucapan huruf perhuruf konsonan alphabet Arab sebanyak 29 huruf kemudian diteruskan dengan mengeja dengan huruf vocal; kedua, belajar cara membaca seluruh kata, kemudian dilanjutkan dengan membaca al-Qur'an, baru setelah tamat membaca al-Qur'an dan pengucapannya bagus diperbolehkan untuk menghapal al-Qur'an.

Tidak hanya sampai pada proses penghapalan al-Qur'an, Robinson menjelaskan bagaimana komunitas muslim yang memelihara hapalannya, bahkan memperlombakannya. Seperti dikutip berikut:

"By discipline and determination, to keep the Qur'an fresh in one's memory. This is the best done by reading it through once a week or,

${ }^{14}$ Neal Robinson, Discovering.....hlm. 16. Pembahasan serupa dapat dilihat pula pada Abdullah Saeed, The Qur'an:.....hlm. 84. 
failing that, once a month. To facilities this practice, some editions have medallions in the margins to divide the text into seven parts of approximately equal length, and most have medallions to indicate the division into thirtieths."

Sebagaimana ditegaskan Robinson, menghapal al-Qur'an harus dibarengi dengan konsistensi penghapal, yakni disiplin tinggi. Dan untuk menjaga hapalan agar tetap melekat pada pikirannya, harus dilakukan pengulangan, baik perminggu atau perbulan, bahkan diperlombakan untuk mengukur kekuatan hapalan muslim terhadap al-Qur'an.

Sebagaimana Robinson, Saeed juga mengungkapkan bagaimana sepanjang sejarah Islam, pembacaan dan penghapalan al-Qur'an telah menjadi tradisi yang mengakar kuat di kalangan umat Islam, sebagaimana diungkapkan:

"Throughout the history of Islam, the qur'an has always been much more than a legal or religious text used mainly by scholars and preachers. From its revelation in the seventh century, the Qur'an has been memorized, recited and to a lesser extent copied by people at all levels of society, from scholars to young children. Recitation of the Qur'an has always been a central part of Muslim religious practice...... Whether it is in daily prayer, or to open formal meetings or informal social gatherings, parts of the Qur'an are recited daily by Muslims throughout the world." 16

Jelas bahwa fenomena penghapalan al-Qur'an sebagaimana dikuatkan Saeed telah terjadi sepanjang sepanjang sejarah Islam, terlebih oleh para ulama dan da'i, al-Qur'an bukan hanya dimanfaatkan sebagai teks hukum atau agama. Al-Qur'an telah hafal, dibacakan, disalin oleh hampir setiap kalangan dan lapisan masyarakat. Sejak usia anak-anak hingga dewasa, pembacaan dan penghapalan al-Qur'an selalu menjadi bagian sentral dari praktik keagamaan umat Islam. Bahkan praktik keindahan seni pembacaan dan penghapalan al-Qur'an dikompetisikan sampai tingkat internasional. Selain itu, sebagaian ayat yang digunakan untuk doa sehari-hari, atau untuk membuka rapat resmi atau pertemuan informal.

\footnotetext{
${ }^{15}$ Neal Robinson, Discovering ......, hlm.17.

${ }^{16}$ Abdullah Saeed, The Qur'an: ......,hlm.84.
} 
Dari fenomena di atas, jelas bahwa penghapalan al-Qur'an menjadi tuntutan umat Islam dalam rangka mensahkan ibadah solat mereka dan sekaligus menjadi kebutuhan untuk mengsakralkan sekaligus memberikan spirit pada setiap praktik ibadah dan praktik sosial keagamaan atau pun social kemasyarakatan.

\section{Al-Qur'an dalam Keseharian: dari Media Elektronik Hingga Jimat}

Dari pemaparan fenomena muslim dalam menjaga intensitasnya bersama al-Qur'an di atas, dijelaskan bahwa menghapal al-Qur'an hampir bisa dikatakan 'wajib' bagi umat Islam. Meskipun demikian, kenyataan di mayoritas umat Islam hal ini sangat memberatkan, melewati banyak tahapan seperti dijelaskan di atas, belum lagi keharusan untuk menjaga hapalan sepanjang hidup, di tengah era modern saat ini, tentunya menjadi kendala tersendiri bagi umat Islam. Neal Robinson juga melihat fenomena tersebut ketika melakukan penelitiannya di Pakistan. Hal yang menarik baginya ketika umat muslim menyikapi hal itu dengan menghadirkan al-Qur'an dalam kehidupan sehari-hari dengan cara yang berbeda. Robinson merekam fenomena itu sebagaimana diungkapkannya:

"Comparatively few have determination to learn the whole Qur'an by heart. Even fewer have the talent or the opportunity to perfect their recitation so as to reproduce' that' inimitable symphony, the very sounds of which move men to tears and ecstacy. Many get no further than memorizing half a dozen short surahs well enough to recite them falteringly in their prayers. How does the Qur'an impinge on the everyday lives of ordinary muslim like them? Modern technology has greatly increased the opportunities for hearing high-quality recitation throughout the year.",17

Dari statement di atas, Robinson minimnya tekad orang Islam untuk menghapal seluruh al-Qur'an. Bahkan menurutnya, lebih sedikit umat Islam yang memiliki bakat atau kesempatan untuk menyempurnakan bacaan mereka dengan tilawah yang menghasilkan suara merdu sekaligus dapat menggerakkan hati pendengarnya sedih dan gembira. Banyak muslim yang tidak mendapatkan melanjutkan menghafal al-Quran, bahkan terbata-bata dalam melapalkan bacaan

\footnotetext{
${ }^{17}$ Neal Robinson, Discovering.....hlm.17-18.
} 
al-Qur'an. Robinson mempertanyakan fenomena itu. Menurutnya, bagaimana alQur'an dapat hadir dalam kehidupan sehari-hari muslim? Dalam hal ini, bantuan teknologi modern, media elektronik seperti radio, casset, dan sebagainya telah meningkatkan intensitas muslim dalam memperdengarkan bacaan al-Qur'an yang berkualitas lewat qori-qori yang terkenal bagus bacaannya, misalnya Mahmud Khalil al-Husairi dari Mesir dan Ghulam Rasul dari Pakistan.

Al-Qur'an tidak hanya bacaan yang sehari-hari diperdengarkan oleh orang Islam, di sisi lain, ternyata al-Qur'an memiliki fungsi lain. Dengan kata lain, umat Islam membaca ayat atau surat tertentu untuk maksud tertentu, misalnya sebagai pelindung, obat, jimat dan lain-lain. Neal Robinson menangkap fenomena tersebut dalam ungkapannya:

"Passages from the Qur'an are sometimes copied out and used for superstitious practices, especially by muslims from the more backward rural areas. For instance Surahs 113 and 114, which are prayers for protection from evil, are worn as amulets. ",18

Dari kutipan di atas, Robinson melihat fenomena muslim yang berbeda dalam memfungsikan al-Qur'an di luar fungsinya sebagai kitab suci yang harus dijaga, dipelihara, dibaca, dihapal dan diamalkan isi kandungannya. Dari pengamatannya, Robinson melihat bagaimana sebagian umat Islam terkadang menjadikan ayat-yat al-Qur'an untuk praktik-praktik pengobatan dan ritual-ritual takhayyul. Selain itu, ia juga menjelaskan bagaimana QS. al-Falaq dan al-Nas dijadikan sebagai jimat, mantera pelindung, obat penyakit, dan lain-lain. ${ }^{19}$

Hampir senada dengan yang dikemukakan Farid Esack dalam pembahasannya tentang “The Qur'an In The Lives of Muslims: The Qur'an is alive". Sebagaimana diungkapkan:

"For Muslim the Qur'an is alive and has a quasi-human personality. I have come across friends in India who do not change in their bedrooms in deference to and respect for the fact that " there is a copy of the alQur'an on the top shelf". The Qur'an, Muslim believe, watches over us and will intercede with God for us on the day of Judgment. .....Passages from it are used as amulets to protect from illness or "the

\footnotetext{
${ }^{18}$ Neal Robinson, Discovering ..... hlm. 21.

${ }^{19}$ Fenomena ini diungkapkan juga oleh Abdullah Saeed, Al-Qur'an: .... hlm.87.
} 
evil eye": a few verses containing the prayer that the Qur'an sugest Noah offered when he entered the ship are stuck on the windscreens of vehicles from Chicago to Jakarta to offer protection to the driver and passengers ${ }^{, 20}$

Dari kutipan di atas, Farid Esack menjelaskan bagaimana Al-Qur'an dianggap sebagai bagian dari kehidupan dan menguasai kepribadian umat Islam. Sebagai bentuk penghormatan, umat Islam masih menempatkan kitab suci alQuran pada posisi yang lebih tinggi kedudukannya, misalnya di bagian paling atas rak. Sebagai bentuk keyakinan, mereka meyakini bahwa Al-Qur'an akan mengawasi dan memberikan syafaat pada hari kiamat kelak. Dan sebagai media pelindung, mereka menggunakan al-Qur'an sebagai jimat untuk melindungi dari penyakit fisik ataupun non fisik-gangguan setan, jin dan sejenisnya-dan melindungi diri dari marabahaya ketika sedang naik kendaraan atau pun pesawat.

\section{Fadilah al-Qur'an: Diantara Ayat dan Surat Favorit}

Sebenarnya fenomena hadirnya al-Qur'an dalam kehidupan muslim sudah ada sebelum munculnya teknologi modern bidang media elektronik. Beberapa kata dalam al-Qur'an kerap kali digunakan untuk mengekspresikan pikiran dan perasaan umat Islam. Robinson merekam fenomena itu sebagaimana berikut:

"Before the advent of radio and the cassete recorder, however, the Qur'an had already left an indelible impression on the arabic language, and Qur'anic expressions had passed translated in to the everyday speech of non-Arab muslims, who outnumber Arabs by about seven to one. ${ }^{, 21}$

Dari redaksi di atas, Robinson menegaskan bahwa sebenarnya, jauh sebelum munculnya media elektronik, diakuinya al-Qur'an telah terbiasa diucapkan dalam keseharian umat Islam, baik dalam percakapan sehari-hari atau acara-acar formal, misalnya ungkapan salam muslim as-salamu 'alaikum, insyaallah, mashaAllah, alhamdulillah dan bismillahi 'r-rahman '-rahim.

\footnotetext{
${ }^{20}$ Farid Esack, The Qur'an: ......hlm. 17.

${ }^{21}$ Ibid., hlm. 18.
} 
Esack dalam pembahasannya "The Qur'an As the Recited Word of God", menjelaskan bagaimana ayat-ayat dan surat-surat tertentu sering dibacakan pada moment-moment tertentu, sebagaimana diungkapkan:

"In addition to the solace that the Qur'an promises to provide to the believers in the Hereafter, Muslims find in its recitation an enormous source of comfort and healing in this world. It is recited at the bedside of the ill and when they depart from his world, to ease the passage of the departed soul into the next and to provide comport for those left behind; as if to say "whatever, be assured God is here; just listen to His speech!". For Muslim, the Qur'an is possessed of enormous power: ",22

Bagi orang muslim, sebagimana dituturkan Farid Esack di atas, al-Qur'an memiliki kekuatan yang sangat besar. Selain sebagai penghibur, al-Qur'an bagi orang-orang mukmin adalah sumber kenyamanan dan penyembuh bagi yang sakit di dunia ini. Mereka membacakan al-Qur'an di samping tempat tidur orang yang sakit dan ketika mereka meninggal dunia, tujuannya untuk memudahkan ruh menuju alam baqa dan memberikan ketenangan bagi keluarga yang ditinggalkan.

Melengkapi pendapat Nelson Robinson dan Farid Esack, Abdullah Saeed dalam pembahasannya tentang "Commonly Recited Verses" menangkap fenomena ayat-ayat favorit yang sering dibacakan oleh umat Islam, sebagaimana diungkapkan:

"Parts of the Qur'an are often recited on both private and public occasions. For instance, a formal speech or important gathering will often be opened and closed with a short reading from the Qur'an. This reading acts as a form of prayer or blessing on the occasion. Often people will choose a number of verses which they feel are appropriate for the occasion, but there are verses that are read more often than others. ",23

Seperti disebutkan di atas, ada sebagian ayat-ayat atau surat dari Al-Qur'an yang sering dibacakan pada acara pribadi dan acara-acara publik, seperi: pidato resmi, pertemuan penting dan pembacaan doa penutup. Misalnya, QS. al-Fatihah sering dibacakan untuk membuka rapat atau pertemuan, QS. al-Ashar sering dibacakan pada penutup sebagai refleksi atas singkatnya hidup dan pentingnya

\footnotetext{
${ }^{22}$ Farid Esak: The Qur'an.....hlm. 18.

${ }^{23}$ Abdullah Saeed, The Qur'an:....hlm.86-87.
} 
mengingat salah satu yang paling penting prioritas dalam hidup, QS. al-Rum: 21 sering dibacakan pada acara pernikahan, QS. Yasin sering dibacakan pada saat orang sakit atau meninggal yang bertujuan untuk meringankan seseorang penderitaan dan siksa kematian.

\section{Kaligrafi al-Qur'an: Ekspresi Artistik dan Nilai Profit}

Di samping menghadirkan al-Qur'an dalam bentuk lisan, umat Islam juga menghadirkan al-Qur'an dalam bentuk tulisan atau biasa disebut dengan seni kaligrafi al-Qur'an. Robinson merekam fenomena tersebut sebagai berikut:

"Be that as it may, the written word now plays an important part in Islam. Because of the prohibition of the visual representation of animate forms, muslim artists have long found an outlet for their creative energy in calligraphy. Throughout the Islamic world, mosques and public building are adorned with quotations from the Qur'an, whether carved in wood, stone or stucco, engraved on metal, painted on tiles, or composed of glazed bricks. In shops, offices and private house one may see calligraphy panels written with brush or reed pen. "24

Dari kutipan di atas, Robinson menjelaskan arti penting keindahan tulisan tangan dalam al-Qur'an. Ia mengilustrasikan bagaimana ayat-ayat al-Qur'an sebagai representasi visual dari adanya pelarangan untuk menggambar hewan dalam ajaran agama Islam, yang kemudian diwujudkan dalam bentuk seni kaligrafi. Melalui dunia Islam, hampir setiap tempat ibadah; masjid, gedung, kantor, toko, rumah dihiasi dengan kaligrafi al-Qur'an dengan berbagai model dan gaya (style) yang variatif.

Senada dengan Robinson, Abdullah Saeed menangkap fenomena seni kaligrafi al-Qur'an ini dalam masyarakat muslim sebagaimana diungkapkan:

"The Qur'an, in its written form, is also found throughout the public and private spheres of Muslim communities. Since the advent of printing, it has become increasingly common for Muslims to own a written copy of the Qur'an, and today there would be one in most Muslim households. ..... Today, the decorative art of Qur'anic calligraphy can be found everywhere from a mosque or mausoleum, to the wall of a Muslim household or the screensaver of a computer. "25

\footnotetext{
${ }^{24}$ Abdullah Saeed, The Qur'an..... hlm. 20.

${ }^{25}$ Abdullah Saeed, The Qur'an:....hlm. 84.
} 
Jelas bahwa seni kaligrafi al-Qur'an dapat ditemukan di setiap lingkungan individu dan masyarakat muslim. Sejak munculnya pencetakan, hampir semua umat Islam meliliki salinan tertulis dari al-Qur'an, baik dalam bentuk kitab atau pun dalam bentuk lain seperti tertulis pada: surat kabar, undangan formal, dokumen keagamaan, masjid, makam, dinding rumah dan bahkan screensaver komputer.

Umat Islam menyadari bahwa seni kaligrafi al-Qur'an adalah bagian terpenting dari ekspresi artistik Islam, sebagaimana diungkapkan Saeed:

"Arabic calligraphy is considered one of the most important forms of Islamic artistic expression. Patterns based on Qur'anic texts are often displayed in mosques, tombs and palaces, as well as in homes, on walls, furniture, tapestries and ornaments, and in secular manuscripts throughout the Muslim world. ..... Calligraphy is highly valued for its strong association with the Qur'an and also because it enables free artistic expression without needing to produce images of sentient beings, a practice which many Muslims believe is discouraged. "26

Kutipan di atas menunjukkan bahwa kaligrafi Arab dianggap sebagai salah satu bentuk yang paling penting dari ekspresi artistik Islam. Pola berdasarkan teks-teks Al-Qur'an sering ditampilkan dalam berbagai tempat, dan berbagai bahan seperti logam, tembikar, batu, kaca, kayu, tekstil dan sering dalam gaya dan fitur yang variatif. Kaligrafi sangat dihargai karena memiliki asosiasi yang kuat dengan Al-Qur'an selain sebagai upaya menghindari seni menggambar mahluk hidup.

Lebih lanjut, Abdullah Saeed menjelaskan perkembangan seni kaligrafi alQur'an, sebagaimana diungkapkan:

"Over time, Muslim artists have developed a variety of styles of calligraphy, which differ from country to country and time to time. Common features across different styles include the interplay of curves and lines, the articulation of words and letters in floral or geometric designs, and a distribution of colours over the whole or part of the text. The subject of calligraphy tends to focus on Qur'anic verses, the names of God, the names and titles of the Prophet and, in the case of Shi' $i$ Islam, the names of the infallible imams.

\footnotetext{
${ }^{26}$ Abdullah Saeed, The Qur'an: ....., hlm. 92.

${ }^{27}$ Abdullah Saeed, The Qur'an:.... hlm. 91.
} 
Jelas bahwa seiring waktu, seniman Muslim telah mengembangkan berbagai gaya kaligrafi, yang berbeda pada setiap negara dan setiap kurun waktu. Namun umumnya menurut Saeed, fiturnya bergaya interaksi kurva dan garis, artikulasi kata-kata dan huruf dibuat dalam desain bunga atau geometris, dan distribusi warna hampir di setiap bagian atau keseluruhan teks. Adapun subyek kaligrafi, umumnya cenderung berfokus pada ayat-ayat al-Qur'an, nama-nama Allah, namanama Nabi, dan nama-nama imam.

Fenomena ini tentunya tidak hanya sebagai upaya pengembangan seni kaligrafi Islam, tetapi lebih dari itu, ada penghargaan yang diberikan dari sebuah keindahan karya seni kaligrafi yang diciptakan. Maka tidak heran jika seni kaligrafi mengalami perkembangan yang pesat karena adanya nilai profit yang didapatkan.

\section{Posisi al-Qur'an: Antara Pedoman Hidup dan Ideologi}

Al-Qur'an adalah pedoman hidup umat Islam. Sebagai pedoman hidup, alQur'an menuntun umat Islam kepada kehidupan yang lebih baik. Namun, pedoman hidup ini akan mengalami perubahan makna ketika dijadikan ideologi kelompok-kelompok tertentu. Farid Esack melihat bagaimana fenomena muslim di Afrika Selatan — bahkan mungkin di seluruh dunia Islam, yang menjadikan alQur'an sebagai alat ideologis. Farid mengungkapkan dalam pembahasannya "The Qur'an As Contested Scripture”:

"In South Africa, as in most of the world muslim, this battle has for long essentially been between traditionalism and modernism. Later, islamists--those seeking to the find a contemporary socio-political expression of Islam--built it on the foundation of the "direct to the Qur'an" approach of the modernists. some of these islamists who often described to all forms of oppression, took this further to see how the Qur'an could be used as an ideological tool in the struggle against racial and class oppression. "28

Dari kutipan di atas, Farid Esack menangkap adanya fenomena muslim yang menjadikan al-Qur'an sebagai alat ideologis dalam perjuangan melawan penindasan rasial dan kelas social. Dimana ketika seseorang menguasai teks dan

\footnotetext{
${ }^{28}$ Farid Esack, The Qur'an.....hlm. 21-22.
} 
memegang kekuasaan untuk menjadikannya sebagai alat untuk mengakses, menafsirkan, melegitimasi berbagai kepentingan individu, kelompok, atu komunitas tertentu. Kasus pertentangan antara kaum tradisionalis dan modernis yang terjadi di Afrika Selatan adalah contoh kasus bagaimana al-Qur'an dijadikan argumenent untuk meligitimasi ideologi kekuasaan sosial-politik.

\section{Kultusasi al-Qur'an: Antara Etika dan Penodaan}

Al-Qur'an adalah diyakini oleh umat Islam sebagai kitab suci. Adanya keyakinan ini memunculkan fenomena pengkultusan terhadap al-Qur'an. Dampak dari fenomena ini diantaranya adalah munculnya etika umat Islam dalam memegang al-Qur'an (Handling The Qur'an) dan mengkultuskannya dari hal-hal yang tidak layak. Abdullah Saeed menangkap fenomena ini sebagaimana diungkapkan:

"Given the strong presence of the Qur'an in the lives of many Muslims, various norms and practices concerning interaction with the Qur'an have developed over time. Some of these practices are universal, known to most Muslims, regardless of the time or place in which they live, while others may be specific to a certain culture or time. The common thread in all these practices is a sense of respect and reverence for the Qur'an as the Word of God and hence as a sacred object. "29

Menurut Saeed, mengingat kehadiran al-Qur'an dalam kehidupan mayoritas umat Islam, berbagai norma dan praktek tentang interaksi dengan alQur'an berkembang dari waktu ke waktu. Beberapa praktek-praktek ini bersifat universal, diketahui sebagian besar Muslim, terlepas dari waktu atau tempat di mana mereka tinggal, sementara yang lain mungkin khusus untuk budaya atau waktu tertentu. Benang merah semua praktek ini adalah sebagai bentuk penghormatan terhadap Al-Qur'an sebagai Firman Allah yang suci.

Menurut Saeed, Imam al-Qurtubi adalah orang yang menggagas etika terhadap al-Qur'an. Secara lebih jelas, Saeed menyebutkan etika membaca alQur'an sebagaimana diungkapkan:

"Qurtubi suggests that, in preparation for reciting the Qur'an, a person should brush their teeth with a siwak (twig used for brushing the teeth)

\footnotetext{
${ }^{29}$ Abdullah Saeed, The Qur'an:....hlm. 84.
} 
and rinse their mouth with water, so that the mouth will be fresh before recitation. People should also sit up straight, dress as if intending to visit a prince, and place the Qur'an on their lap or on something that is off the floor. They should then find a quiet place, facing Mecca, where they will not be interrupted, or where they will need to intersperse their recitation with human words. Recitation should not be done in marketplaces or places of frivolity, and when they start to recite, people should seek refuge in God from Satan. "30

Dari kutipan di atas, secara singkat etika membaca al-Qur'an menurut alQurtubi meliputi: menyikat gigi sebelum membaca al-Qur'an, Posisi duduk tegak, berpakaian rapih layaknya akan mengunjungi raja, menempatkan Qur'an di pangkuan atau tempat di atas lantai, harus mencari tempat yang tenang, menghadap ke Mekah, tidak menyelingi bacaan dengan perkataan, di tempat yang mulia, dan terakhir memulai membaca al-Qur'an dengan ta'awudz.Menurut Saeed, al-Qurtubi juga merekomendasikan bahwa umat Islam harus membaca seluruh bagian dari Al-Qur'an, bukan hanya beberapa ayat di sana-sini. Dia lebih lanjut menunjukkan bahwa mereka harus membaca dengan santai agar lebih konsentrasi, mengucapkan setiap huruf dengan jelas, dan menggunakan 'kursi untuk Quran' atau buku pemegang untuk untuk menghindari tergeletak di lantai.

Fenomena kultusasi al-Qur'an juga terdapat pada bagaimana umat Islam melakukan ritual berwudhu dan bersuci sebelum menyentuh al-Qur'an (ritual purity and cleanliness). Saeed menggambarkan fenomena ini sebagaimana berikut:

"Many Muslims believe that before someone touches or carries the Qur'an, they should be ritually pure. This involves going through the same purification ritual that a Muslim would undertake before performing the five daily prayers. Some will also attempt to ensure that their clothing is clean and that they are dressed modestly as a further sign of respect. ${ }^{, 31}$

Sebagaimana disebutkan, mayoritas umat Islam percaya bahwa sebelum seseorang menyentuh atau membawa al-Qur'an, mereka harus dalam kondisi suci dari hadas besar maupun hadas kecil sebagaimana akan melaksanakan ibadah

\footnotetext{
${ }^{30}$ Abdullah Saeed, The Qur'an:.... hlm. 88.

${ }^{31}$ Abdullah Saeed, The Qur'an:....hlm. 88.
} 
solat. Selain suci secara batin, seseorang yang akan memegang al-Qur'an juga harus bersih secara lahir, berpakaian bersih sebagai wujud penghormatan terhadap al-Qur'an.

Fenomena kultusasi al-Qur'an selanjutnya adalah memuliakan tulisan ayat al- Qur'an dari tempat-tempat atau benda-benda yang kotor. Abdullah Saeed dalam pembahasannya menyebutnya dengan "Desecration of the Qur'an" (Penodaan terhadap al-Qur'an). Kasus tentara Amerika di Teluk Guantanamo pada April 2005 telah membuang bagian dari ayat al-Qur'an ke dalam toilet menjadi pemicu marahnya umat Islam terhadap peristiwa tersebut. Ini membuktikan bagaimana umat Islam begitu mengkultuskan kitab suci al-Qur'an.

Fenomena kultusasi ini pun berdampak pada bagaimana umat Islam harus membakar atau mengubur kertas atau benda-benda yang bertuliskan ayat-ayat alQur'an. Saeed mengungkapkan:

"A common view among Muslims is that such material should not be thrown out with or put in the same place as rubbish. Instead, it should be burnt or buried. Although respectful of the Qur'anic text, this view can create practical problems in some countries, such as in the Middle East, where inclusion of Qur'anic phrases in the newspaper is very common ${ }^{, 32}$

Dari kutipan di atas dijelaskan bahwa mayoritas pandangan umat Islam berpendapat bahwa benda atau materi yang terdapat ayat-ayat al-Qur'an tidak boleh dibuang dengan cara dimasukkan ke dalam tempat tempat sampah. Sebaliknya, harus dibakar, dikubur atau didaur ulang asalkan kertas tidak dicampur dengan limbah umum. Meski inipun ada sebagian umat Islam ada yang berpendapat bahwa daur ulang bahan Qur'an adalah terlarang.

\section{Penutup:}

\section{Menarik Benang Merah}

Harus diakui bahwa kajian yang telah dilakukan oleh Neal Robinson, Farid Esack dan Abdullah Saeed dalam mengkaji fenomena umat Islam dalam berinteraksi dengan al-Qur'an adalah hasil karya yang sangat menarik dalam

\footnotetext{
${ }^{32}$ Abdullah Saeed, The Qur'an:....hlm. 91.
} 
kajian living Qur'an. Apa yang telah dilakukan ketiganya ketika melihat realitas umat Islam dalam memperlakukan al-Qur'an dalam kehidupan sehari-hari secara variatif. Dari semua fenomena yang disebutkan di atas, penulis sepakat dengan pernyataan pendapat Abdullah Saeed: "The common thread in all these practices is a sence of respect and reverence for the Qur'an as the World of God and hence as a sacred object," bahwa benang merah dari semua praktik ini adalah sebagai wujud pengaguman dan penghormatan terhadap al-Qur'an sebagai firman Allah SWT. yang terjaga kemurniannya. Wallahu A'lam bi al-shawab. 


\section{DAFTAR PUSTAKA}

Baharun, Hasan, 2011. "Mohammed Arkoun: Pendekatan Antropologi dalam Membumikan al-Qur'an dalam Metodologi Studi Islam: Percikan Pemikiran Tokoh dalam Membumikan Agama, Yogyakarta: Ar-Ruzz Media.

Esack, Farid, 2005. The Qur'an: A User's Guide, England: One World Oxpord.

Robinson, Neal, 2003. Discovering The Qur'an: A Contemporary Approach To A Veiled Text, Washington: Georgetown University Press, $2^{\text {nd }}$ ed.

Saeed, Abdullah, 2008. The Qur'an: An Introduction, London and New York: Routledge.

Syamsuddin, Sahiron, 1999. "Penelitian Literatur Tafsir/ Ilmu Tafsir: Sejarah, Metode dan Analisis Penelitian (Makalah seminar ), Yogyakarta. Disampaikan pada Sarasehan Metodologi Penelitian Tafsir-Hadis IAIN Sunan Kalijaga Yogyakarta pada tanggal 15-16 Maret 1999. 